\title{
Spontaneous Development of Forests of the Central Russian Upland is Desirable
}

\author{
Yuri Fiodorovitch Arefjev \\ Department of Ecology, Forest Protection and Hanting Studies, Faculty Forestry, Voronezh State University of Forestry and Technologies, \\ Voronezh, Russia
}

Email address:

arefjev@voronezh.net

\section{To cite this article:}

Yuri Fiodorovitch Arefjev. Spontaneous Development of Forests of the Central Russian Upland is Desirable. American Journal of BioScience. Vol. 5, No. 6, 2017, pp. 89-103. doi: 10.11648/j.ajbio.20170506.11

Received: September 25, 2017; Accepted: October 6, 2017; Published: November 6, 2017

\begin{abstract}
Forests life depends in many respects from specific of mankind activity. Adverse aspect is destruction and degradation of the natural old-growth woods. The woods have been ruthlessly affected by humans. The man-made forests usually have the low level of heterogeneity and are object of mass attacks of harmful organisms. The purpose of this work is to prove formation of the forest ecosystems capable to spontaneous development, to biotic self-control. Spontaneous development is a basis of free choice of the Nature and a rather high level of heterogeneity of created plantings. It is desirable. Long-term researches were carried out in the conditions of the Central Russian Upland. Results of experimental forest works of 1936 are considered. The methodology of researches was based on the comparison of a condition of viability of forest stands and natural renewal in plantings, various on heterogeneity level. Level of heterogeneity of mosaic forest ecosystems at which spontaneous development conducting to biotic self-control of species communities and maintenance of biotic systems is reached, was as a result of researches established. Equability of man-made forests is thus to almost necessary level reached.
\end{abstract}

Keywords: Forests, Degradation, Heterogeneity, Upland, Self-Control

\section{Introduction}

The transformation of forested lands by human actions for a long time of industrial history promoted deep natural and social changes on our Earth. Globalization of negative climatic and other problems increasingly allows International interactions and cooperation. To overcome the undesirable consequences of deforestation, to resist the prolonged forest degradation and reduction in forest quality it is offered to form forest ecosystems which are capable to spontaneous development and to biotic self-control on the example of plantings of the Central Russian forest-steppe. Basis of it is a rather high level of heterogeneity of created plantings.

In this regard the study, Arefjev [1] proposed a twouniform, ecology-genetic, approach to forest protection, Björkman [2, 3] investigated resistance to diseases of forest plants, Flor [4] offered the concept of the "gene-for-gene". It is known that in beginning our Earth was created with a rich "fur coat" on its body. Woods were this "fur coat". Woods were one of the major factors that formed our planet and influenced the mutual co-adaptation of the environment and life. The ecological situation then was favorable for human being. But mass deforestation and forest degradation, harmful organisms, lax forest management on the huge territory reduced strongly both an ecological and social values of forests, especially strongly in the Central Russian forest-steppe. The critical problem consists in restoring of the natural values of forests as a powerful regulator of environment. The aim of this study is to promote the decision of the problem on a genetic-ecological basis and rational forest management of practices.

The present paper is the justification of a sustainable development of forest ecosystems on the example of the plantings of the Central Russian forest-steppe. It will be a local contribution to improvement of an ecological situation on Earth. Private questions of the forest protection of against pathogenic organisms are discussed.

The long-term researches were carried out in the conditions of the Central Russian forest-steppe. Results of experimental forest works of 1936 are considered. The methodology of researches was based on the comparison of a condition of viability of forest stands and natural renewal in 
plantings, various on heterogeneity level.

Forest plantings of this region are especially subject to adverse effects of biotic, abiotic and anthropogenous factors. The methodology of research is based on the description of plantings and an assessment of their pathological state (state of health) on transects. Interpretation of parameters of quantitative signs was carried out from positions of Mendel [5] laws and Hardy [6] and Weinberg [7] law. Methodical approach of $\mathrm{S}$. $\mathrm{Li}[8,9]$ for the population analysis of result of research was used. From this viewpoint the forest tree disease is the multifactorial phenomenon. Quantitative traits are phenotypes that vary in degree and can be attributed to polygenic effects and their environment. Such traits are controlled by the both environment and genetic factors with use of methodical approach of S. Löchelt [10].

The assumption of polygenic inheritance is that all involved loci make an equal contribution to the symptoms of the plant disease. The Hardy-Weinberg law (equilibrium) states that genotype frequencies in a population will remain constant from generation to generation in the absence of other evolutionary influences. Thus there is possible a free choice of the Nature in forest ecosystems: the interspecific competition, natural selection, allelic drift, influence of mutations, miss - and inbreeding. The minimum sites of plantings for autoregulation of forest biocenoses were defined. The species composition of communities according to forest vegetation conditions were defined according to forest vegetation conditions were defined.

As result, researches showed the need of transition from homogeneous forest cultures to formation of highly heterogeneous mosaic plantings. Such plantings are more open for a free choice of the nature and provide a sustainable development of forest ecosystems in the conditions of the changeable world. The offered management strategy overcomes the negative effect of man-made forests which usually have the low level of heterogeneity and are object of mass attacks of harmful organisms.

\section{Oak and Pine Plantings of the Central Russian Forest-Steppe as a Dwelling of Parasitic Fungi and Insects}

Modern typical landscape of the Central Russian foreststeppe includes extensive agricultural fields, small sites of the natural steppe, rivers and ravines and islands of the oak and pine forests (Figure 1).

The climate in the region is temperate continental, with average January temperatures of $-4.5^{\circ} \mathrm{C}\left(23.9^{\circ} \mathrm{F}\right)$, and with average July temperatures of +25 to $+30^{\circ} \mathrm{C}\left(77\right.$ to $\left.86^{\circ} \mathrm{F}\right)$. Average annual temperature varies from $+5^{\circ} \mathrm{C}\left(41^{\circ} \mathrm{F}\right)$ in the north to $+6.5^{\circ} \mathrm{C}\left(43.7^{\circ} \mathrm{F}\right)$ in the south. Such average annual temperatures are favorable for development of autochthonic and many introduced forest tree species, such as Red oak (Quercus rubra), European larch (Larix decidua), White pine (Pinus strobus), and Norway spruce (Picea abies). But the last climatic changes involve unexpected problems. For example, noticeable warming and moistening of weather conditions caused a mass invasion of an Ash borer (Agrilus planipennis) who promoted mass dying off a European ash (Fraxinus excelsior). The climate here becomes specific: the typically Russian continental winter with thorny frosts and large mountains of snow and dry hot summer winds they were replaced by long thaw, fogs, and small-drop rains. In general, present weather reminds sometimes the subtropical climate. Precipitation varies from 700 millimeters in the northwest to 650 millimeters in the southeast. But they are very uneven and irregular.

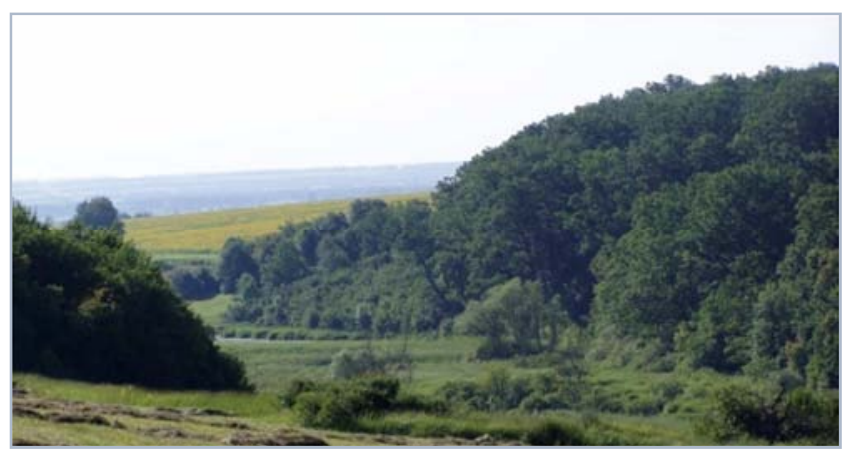

Figure 1. Typical Landscape of the Central Russian Forest-Steppe.

The structure of described region is industrial-agrarian. As part of the industry the mechanical engineering (machine tools, oil and gas equipment, rocket engines, metal bridge structures), electronic equipment, power systems engineering, food industry, mining equipment, passenger aircraft, processing industry of agricultural raw materials dominate. They account for $\approx 80 \%$ from all production. In Lipetsk the Ferrous metallurgy is the most developed branch in the Russian industry. The Mikhailovsky mining and processing combine (Kursk region) is a leading producer of iron ore deposit. Its annual production output reaches approximately 18 million tons of iron ore and 10 million tons of pellets. The biggest energy producers are the Voronezh and Kursk nuclear power plant. It supplies electricity to most of the regions in Russia's Central federal district.

The agriculture is well developed. Fertile black soil steppes are initially and now its basis. Steppes are turned into arable lands. Agricultural lands have been seriously affected by soil erosion and man-made environmental problems. Erosive processes in the territory of the region are very considerable. Especially Voronezh area is major supplier of agricultural products. Annually farms receive big or record crops of sugar beet, sunflowers, potatoes and high-grade grain crops (first of all wheat). Cattle and pigs breeding is highly developed. Horse breeding produces trotters. Only the fish breeding lags behind modern level. Private gardening (mainly apple-trees, pear-trees and plum-trees) is developed as well.

The forest resources lie within $10 \%$ of the all region's area, and are represented mainly by wood of Common oak, Scots pine, Silver birch, European ash, Green ash, Norway ash, Tatar ash, Lime tree, Common alder, and Common aspen. 
Some introduced species of trees also well here grow among them European larch, Tsuga, Norway spruce. As a small component of the UNESCO World Network of Biosphere Reserves Voronezhsky and Novochopyorsky biosphere reserves are situated in the region.

The problem of ravines, of the big and small rivers is very important and actual. There are considerable free territories where the wood did not grow earlier. The goal is to green these territories in the Central Russian forest-steppe. In some places, forests need help to reestablish themselves because of environmental factors.

The effects of both natural and anthropogenic critically worsened a state of health of the woods of the studied region. This problem is especially difficult in areas with high population density and a high proportion of cultivated lands, due to the complex interactions between diverse controlling factors.

Erosive processes in the territory of the Central Russian forest-steppe are very active (Figure 2).

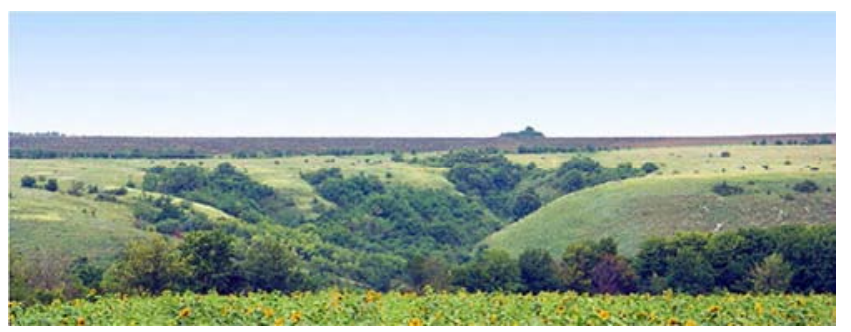

Figure 2. Ravines in the Central Russian Forest-Steppe.

Though Ravines is in principle a natural process (rill erosion is well visible mechanism of soil loss from sloping), its rate has increased significantly during the last century mainly by human activity. Wrong plowing of steppe slopes led to sharp increase in a network of ravines. The soil erosion rate in cultivated fields was correlated with slope positions and crop cover types. The nature of rill erosion in different slope positions creates severe limitations to sustainable agricultural land use. Soil erosion is affecting food and ecological security. The big economic losses from decreased agricultural production are inevitable. Thus, an erosion of soils in the Central Russian Upland is serious environmental problem. Its decision is most rational on the basis of creation of the self-organizing adaptive forest ecosystems.

The problem of afforestation of ravines, of the big and small rivers is very important and actual. There are considerable free territories where the wood did not grow earlier.

The perspective purpose of this work consists in promoting improvement of the forests on the basis of respect and activities of natural laws of formation of forest ecosystems. Thus the forests are formed, capable to autoregulation of pathogenic processes and to natural restoration. Artificially created ecological communities will function as natural biotas, undisturbed by humans. The reconstructed forests will execute a decisive role in improvement of landscape ecology.

Reforestation and afforestation are categories of forestation (the planting of trees over a wide area) which are very important in ecological sense.

Most common (often meet and have economic value) fungal diseases which are usually a considerable threat to tree planting in the studied region are following: annosum root and butt rot (pathogen - infecting agent is a basidiomycete fungus Heterobasidion annosum), oak powdery mildew (pathogen - infecting agent is ascomycete Erysiphe alphitoides), armillaria root rot (infecting agent is Armillaria mellea), trunk and limb rot of hardwoods (infecting agents: Laetiporus sulphureus, Inonotus dryophilus, Phellinus robustus, Phellinus igniarius, Phellinus tremulae, Inonotus obliquus, Fomes fomentarius, Polyporus squamosus, Oxyporus populinus, Daedalea quercina, Piptoporus betulinus, Inonotus dryadeus, Ganoderma applanatum), needle rust of pine (infecting agent Coleosporium spp.), leaf spots (infecting agents Rhytisma acerinum, Rhytisma salicinum, Dothidella betulina, Dothidella ulmi, Cercospora microsora, Gloeosporium quercinum, Gloeosporium tremulae), leaf rust (infecting agent Melampsora pinitorqua).

Effective protection of the forests against pathogenic organisms without use of pesticides is actual. Forest management policy is directed first of all on improvement of plantings of the region. The forests of the studied region representing the greatest interest from the forest protection positions are following: Shipov Oak Forest, Khrenovsky Forest, and Usmansky forest.

Forest station and afforestation are categories of forestation which are very important in ecological sense. Most common fungal diseases which are usually a considerable threat to tree planting in the studied region are following: annosum root and butt rot (pathogen Heterobasidion annosum), oak powdery mildew (pathogen Erysiphe alphitoides), armillaria root rot (pathogen Armillaria mellea), trunk and limb rot of hardwoods (pathogens: Laetiporus sulphureus, Inonotus dryophilus, Phellinus robustus, Phellinus igniarius, Phellinus tremulae, Inonotus obliquus, Fomes fomentarius, Polyporus squamosus, Oxyporus populinus, Daedalea quercina, Piptoporus betulinus, Inonotus dryadeus, Ganoderma applanatum), needle rust of pine (pathogen Coleosporium spp.), leaf spots (pathogens Rhytisma acerinum, Rhytisma salicinum, Dothidella betulina, Dothidella ulmi, Cercospora microsora, Gloeosporium quercinum, Gloeosporium tremulae), leaf rust (pathogen Melampsora pinitorqua).

Protection of the forest against pathogenic organisms without use of pesticides is in the center of attention of the forest protection now. Forest management policy is directed first of all on ecological and genetic improvement of forest plantings of the region. The forests of the studied region representing the greatest interest from the forest protection positions are following: the Shipov Oak Forest, Khrenovsky Forest, and Usmansky Forest.

Sites of the virgin steppe (Figure 3 ) and the natural wood (Figure 4) are rare. 


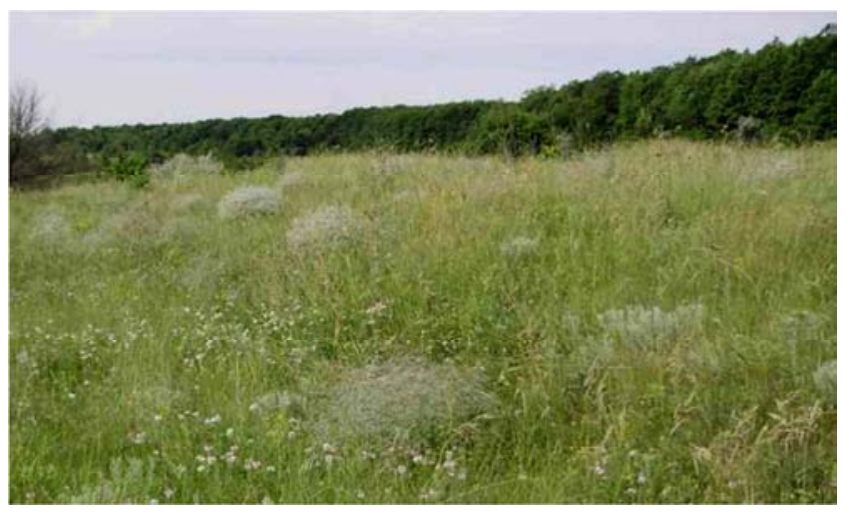

Figure 3. The Sites of Virgin Steppe.

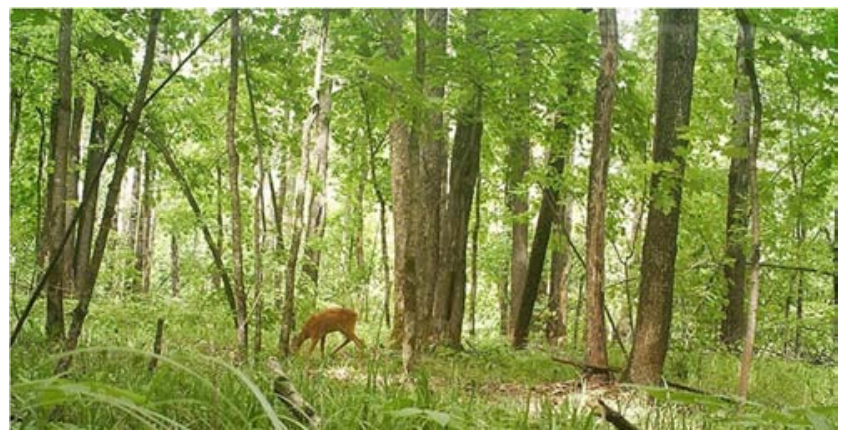

Figure 4. The Sites of Natural Wood.

\subsection{Shipov Oak Forest}

Shipov Oak Forest, situated in Voronezh Oblast on the right bank of the Osered' River, has an area of 39,200 ha. It is the largest insular oak forest on the southeastern border of the forest-steppe region, and it is very important for water storage and land protection. Unwooded ravines divide the forest into three parts. An area of 35,600 ha is covered by trees, including oak (Quercus robur) - 92 percent, ash (Fraxinus excelsior) - 3 percent, and aspen (Populus tremula) - 2 percent); maple (Acer platanoides), elm (Ulmus laevis), linden (Tilia cordata), and other species account for 3 percent of the forested area. The most common component of forest biome are ash and aspen. The oak stands of Shipov Forest produce large volume of high-quality timber. Oak trees here are not only mighty and big, but also surprisingly slender. Shipov forest is the largest island oak-forest in the Central Russian Upland and is the pride of Voronezh region.

In 1709, Peter I had the forest reserved for the use of the shipbuilding industry. Then it was primeval oak 400-450year-old forest. This forest was free from excessive activity of parasitic for trees fungi and insects. In 1908 projects in experimental forestry were begun in the forest. The Central Scientific Research Institute of Forest Genetics and Selection maintains a forest genetics and breeding laboratory in Shipov Forest. And now Shipov forest is the largest island oak forest (an area of 39,2 thousand ha) in the south-east of the great Russian upland.

The landscape analysis allows claiming that Shipov Forest is the rest of the extensive woods which were earlier covering considerably the most part of the Voronezh region. Its role in formation of climate, the water preserving and soil-protective functions in the region was historically very big. Modern task is the restoration of a seed oak forest.

Though the composition of tree species in the forest generally corresponds to growth conditions, parasitic mushrooms and insects are excessively active here. The greatest losses are caused by Armillaria Root Disease. The type pathogen is Armillaria mellea. Honey fungus grows on living, decaying, and dead plant material. Honey fungus is a "white rot" fungus, which is a pathogenic organism that affects generally oak trees and shrubs. This pathogen can grow on living, decaying, and dead forest plant material. Armillaria disease often develops into an epiphytotic, causing heavy mortality in oak stands.

Robustus conk of Phellinus robustus infects 1,6\% of oak trees, causes premature dieback and windthrow of oak trees. Igniarius conk Phellinus igniarius. Infects $1,3 \%$, trees of Willow, Salix sp., Birch (Betulav sp.) and Alder (Alnus sp.). Laetiporus sulphureus develops decay in trunks of living trees, causing weakening at the root- stem base and predisposing trees to wind breakage. Trees may dieback and become hollow. Decay in oak stands affected by the fungus occurs in $1,8 \%$ of the trees. Commercial wood losses can exceed 20 percent. The pathogen Inonotus dryophilus causes crown dieback and radial increment losses. Decayed trees in affected oak stands from $0,8 \%$ to $1,2 \%$. Commercial wood losses can reach 30 percent. The pathogen Erysiphe alphitoides, is the most common here. All oak trees without exception are infected with powdery mildew.

The Shipov Oak Forest needs protection from diseases and pests on an ecological and genetic basis.

\subsection{Khrenovsky Pine Forest}

The Khrenovsky Forest is situated as an island among the southern steppe of the Central Russian upland. Its uniqueness consists first of all that it is located on border of steppe and forest-steppe zones. In it still the natural pine forests remained, but plantations of Scots pine (Pinus sylvestris) prevail. There is the southern border of this pine natural area. The rich and vital tree cohorts once blanketed the all area of the wood. A lush understory of native grasses and a wide variety of herbaceous groundcover formed diverse fauna. But today, similar sites of the forest remain less than 10 percent.

Wildlife is roughly broken. Improper forest management promoted mass distribution of some species of pathogenic organisms and forest pests. Remaining natural pine systems are less damaged by pathogenic organisms.

Now artificially created plantings prevail. Mistakes in silvicultural production led to mass distribution of some species of pathogenic fungi and insects. The disease Annosum Root and Butt Rot is especially harmful.

The pathogen Heterobasidion annosum causes massive decline and death of stands and significant changes in stocking. In many pine plantings, existing disease centers are characterized by weakened and dying trees, previous-year dead trees, and tipped and wind thrown trees. Group 
mortality and blowdown occur and grassy glades develop in the opening. The decay develops in the root system. The disease is rare in natural pine stands. Mixed coniferoushardwood stands are more resistant to the disease. Weakening and decline of infected trees usually results in bark beetle and wood-borer infestations. Among destructive insects the bark beetle has the greatest value.

Most man made pine plantings are especially susceptible to infection of Heterobasidion annosum. In the plantings damaged by a mushroom becomes more active usually Tomicus minor.

The cockchafer, called May bug is a beetle of the genus Melolontha, in the family Scarabaeidae. These insects are very harmful in the pine. These insects are very harmful in the Khrenov pine wood. Modern pest control is insufficiently effective. People have no effective means to protect their pine forests. At present, no chemical pesticides are approved for use against cockchafers, and only biological measures are utilised for control: for instance, pathogenic fungi or nematodes that kill the grubs are applied to the soil.

The modern Khrenovsky Forest requires protection. The goal is to grow the forest ecosystems close to virgin woods. In particular, some forests may support an intermediate layer of shrubs. The forest diversity between and within species has to be enriched.

Especially extensive damage to pine plantings is caused by root decay. Annosum root rot is widely regarded as the most economically damaging forest pathogen in temperate forests in the northern hemisphere, including Russia and America. The pathogen in pine plantings is especially harmful. This disease can occur in both natural and planted forest stands but is most problematic following thinning in pine plantations. Annosum can cause tree mortality, reduced growth rates, increased susceptibility to attack by bark beetles, and regeneration failure. The considerable package of measures on protection of a pine against a root rot is recommended. But the problem remains as the recommended protective measures are unacceptable from ecological or economic positions.

The wide distribution of uniform plantations of a Scots pine in the forest territory led to mass development of parasitic for pine fungi and insects. The offered way of pine protection is the result of long-term researches in regions with the increased threat of a pathogen. Initial stage of methodology is the assessment of health of the studied plantings. Special attention was paid on the centers of a root rot and the plantings after thinning. The plantings predisposed to the disease are considered. As a result of the conducted researches it is established that in the conditions of mosaic structure in populations of pathogens there are effects of an inbreeding depression and allelic drift. Mosaic forest ecosystems most correspond to the principle of a sustainable development in the conditions of local changes of environment.

Pine forests are widespread in the forest-steppe. They occur on sandy loams, sands, limestones, and peat bogs. They play an important part in preserving groundwater and raising yields of agricultural crops in arid zones. They also reinforce sands, and mountain slopes and protect against snow avalanches and mud flows. Forest-steppe zones are characterized by forb and steppe pine groves. Although pines can reproduce through natural or artificial means, a selected forestry program greatly improves long-term management options. By following a good forest management plan, landowners can protect wildlife while also taking advantage of valuable timber harvests.

Combining forest management techniques such as clearcutting, selective harvesting and prescribed burning is recommended. Forest openings allow for a considerable amount of sunlight to reach forest floors which helps stimulate the growth of many native grasses and plants. There are different types of techniques used for natural regeneration of pine forests: uneven-aged management and even-aged management. Discussion of the different silvicultural methods employed to get natural regeneration of pines in the Khrenovsky as well in other southern pine forests. Forests can be managed for multiple uses including wildlife habitat. Pine forests can be managed to provide wildlife habitat.

\subsection{Usmansky Forest}

The Usmansky Forest is representative of pine forests growing on sandy deposit along the left bank of the rivers Don and Voronezh. This ecoregion is characterized by a mosaic of forests, steppe, and riverine wetlands. This is a transition zone between the broadleaf of the north and the grasslands to the south.

Here (in the northern part of the Usman Forest) the wellknown Voronezh Nature Reserve is located. It is one of the oldest nature reserves in Russia. The reserve was created in 1927, and covers an area of 31,053 ha.

The tree species in Voronezh Nature Reserve are a combination of pine $(32.3 \%$, oak $(29.3 \%)$, aspen $(19.3 \%)$, birch $(5.7 \%)$, black alder $(5.2 \%)$.

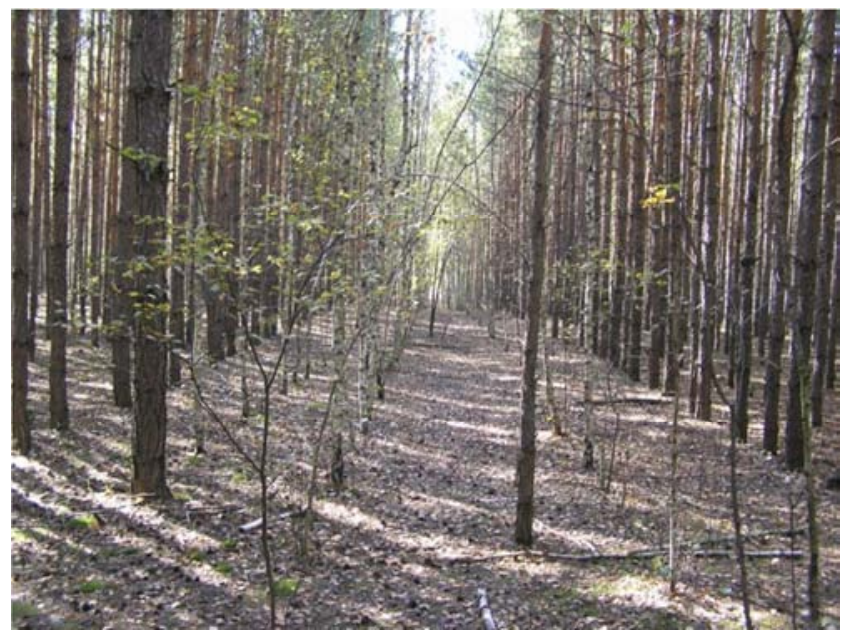

Figure 5. Pine Monocultures. 


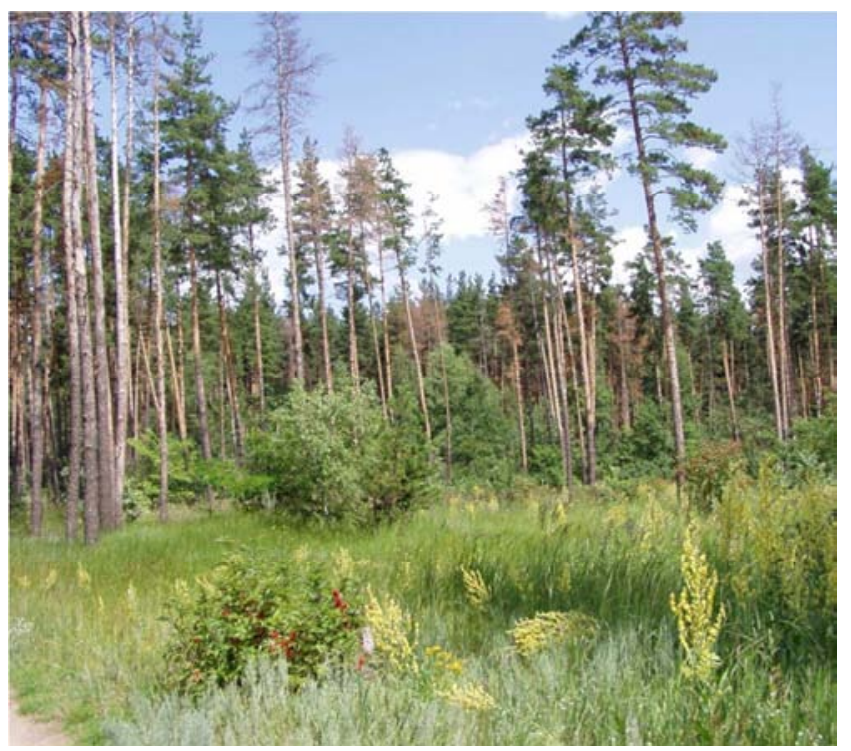

Figure 6. Dying off of the Pine Trees Caused of H. Annosum.

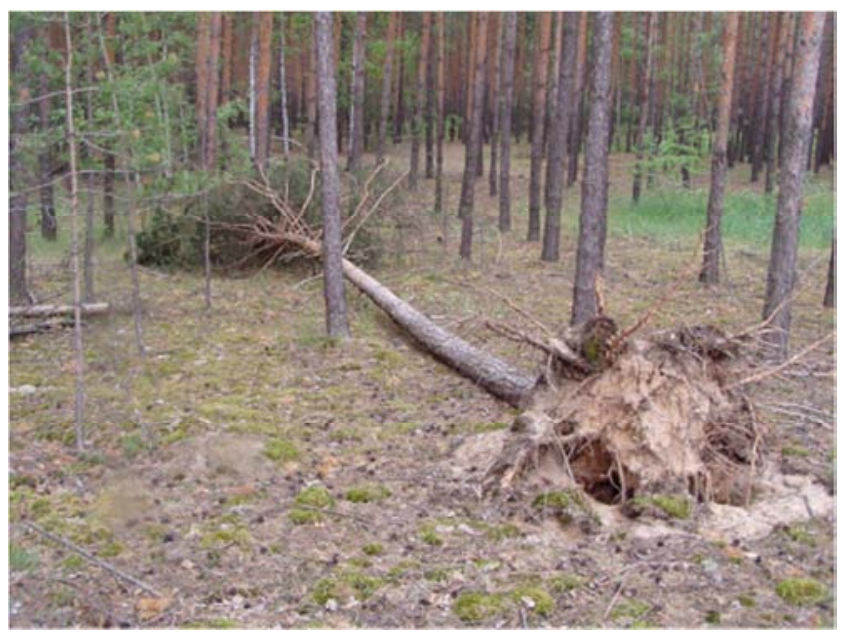

Figure 7. Dead Pine Tree (25-year-old) Infected by H. Annosum.

The pine monocultures (Figure 5) dominate. They are intensively damaged by pathogenic organ isms (Figures 6,7). Among pathogenic fungi in oak plantings the most mass is the Erysiphe alphitoides, causing oak powdery mildew, is a major foliar pathogen of Quercus robur. Young plants of a bass aged till 3 years die off. In mature trees the disease is generally less damaging, it can contribute to tree decline and reduce decorative effect of plantings. In pine planting fungus H. annosum. Annosum root rot is considered to be the most economically important forest pathogen in the Usmansky forest.

To $85 \%$ of oak acorns are damaged of insects. Among them the greatest value has Curculio glandium. It is a species known as the acorn weevil. Its most striking feature is its elongated snout, known as a 'rostrum', which is longer in females than males. The acorn weevil, Curculio glandium, is a widespread parasite of acorns in the oak forests that overwinters in the soil as a larva. It is possible that low temperatures limit its northern geographic range.

As the parasite of oak acorns Cydia splendana occupies the second place. It is also known as the acorn moth.

The bug Aradus cinnamomeus always lives in young cultures of a pine and causes big economic losses. In the same pure pine cultures always big threat for plantings is posed by cockchafers. The Melolontha hipocastany and Amphimallon solstitialis dominate, Melolontha melolontha is rare. Regular visitors of young pine plantings are Neodiprion sertifer. Among butterflies Bupalus piniarius is most significant in pine plantings.

As appears from the provided information, Usmansky's plantings are under strong oppression of parasitic organisms. The general reason for that are the actions against the Nature at creation of forest plantings. Biotic integration in forest ecosystems has to be a basis of the plantings capable to steady development in the conditions of the changeable world. Common pine sawfly (Diprion pini) populations constantly are present at pine plantings. Outbreaks are sporadic.

The problem of protection of pine plantings from Heterobasidion annosum remains as the recommended protective measures are unacceptable from ecological or economic positions and are insufficiently effective. The purpose of this work is to radical increase the efficiency of preventive protection of a pine against a root rot on ecogenetic basis. In subpopulations of the pathogen, the effects of an inbreeding depression, allelic drift and pine group resistance to the pathogen arise. Mosaic forest ecosystems most correspond to the principle of a sustainable development of plantings in the conditions of the changeable environment.

\section{Methodology of Researches}

The methodology of the conducted researches is based on comparison of a state of health of plantings with various level of heterogeneity, as distinctly non uniformity in the main signs and properties $\sigma$ is the significant characteristic of forest objects. Heterogeneity and homogeneity are used relating to the uniformity in communities of organisms.

Homogeneity and heterogeneity are concepts often used in the sciences and statistics relating to the uniformity in a substance or organism.

Statistical analysis are based on comparison of research results with the least difference test at a significance level of 0,05 [11].

One of the main objects for researches has been chosen the pathogen Erysiphe alphitoides. It plays a part in oak decline, which is affected by many factors, e.g. summer drought, winter and spring frost, and various fungi and insects in many areas of Europe. E. alphitoides occurs mainly on Quercus species and causes powdery mildew - Quercus robur is susceptible. A qualitative methodology was used with the collection of data through a series of the long-term investigatios of pathogenic organisms, first of all $M$. alphitoides, caused powdery mildews, in the different growth conditions. The disease powdery mildew is widespread in Europa and is convenient object for quantitative 
investigations. The importance of qualitative and quantitative approaches is that they can provide understanding of distribution dynamics of pathogenic organisms.

The Central Russian forest-steppe is placed in the middle of the European part of Russia. It occupies vast ecologically very heterogeneous landscape. It includes administratively Voronezh, Lipetsk, Kursk, Belgorod, Oryol, Tambov regions. The forest-steppe is characterised by alternation of woods on grey forest-steppe soils and grassy steppes on black soils.

Anthropogenic transformation of environment is very great. The mass deforestation was especially active in 18th century.

Trees were cut down to be used for the military and economic purposes.

Many natural woods have completely disappeared under human activity. They have been cut down. The arable lands prevail. Many water meadows also are arable. The remained woods degrade.

Pathogenic organisms in modern forests are exclusively active. Many coniferous forests have been destroyed by wild fire.

The remained modern forests degrade under action of pathogenic organisms, which are in the study area exclusively active.

The general state of health of the trees and plantings was estimated on a 5 -points scale (Table 1).

Table 1. Scale of the Health State Estimation of Trees and Plantings.

\begin{tabular}{ll}
\hline Characteristic of trees and plantings & $\begin{array}{l}\text { Points of a } \\
\text { health state }\end{array}$ \\
\hline $\begin{array}{l}\text { Healthy tree }- \text { without signs of system easing or } \\
\text { considerable damages }\end{array}$ & 4 \\
$\begin{array}{l}\text { The weakened trees - defoliation }<10 \% \text {, on the average } \\
5 \% \text { a crone green }\end{array}$ & 3 \\
$\begin{array}{l}\text { Diseased trees }- \text { defoliation } 10-50 \% \text {, on the average } 30 \% ; \\
\text { a crone is light green }\end{array}$ & 2 \\
$\begin{array}{l}\text { Dying trees - defoliation }>50 \%, \text { on the average } 75 \% \text {; a } \\
\text { crone has the rests of green elements }\end{array}$ & 1 \\
\hline \begin{tabular}{l} 
The dead trees - without life signs \\
\hline
\end{tabular} & 0 \\
\hline
\end{tabular}

The average point of a state health was defined under the formula:

$$
V=\frac{\sum v \times n}{N}
$$

where $\mathrm{V}$ - average point of a state health, $\mathrm{v}$ - points of a state health of the separate trees, $\mathrm{n}$ - number of trees of separate points, $\mathrm{N}$ - total number of trees.

Dynamics of pathogenic fungi was investigated in the pure and mixed forest stands. Host stands were: oak (Quercus robur) stands, pine (Pinus sylvestris) stands, oak-pine stands, oak-pine-birch (Betula pendula) stands.

Disease development was defined under the formula:

$$
D=\sum \frac{(d \times n) 100}{d_{\max } \times N}
$$

where D - development of disease, $\%, d$ - defeat of the plants, dmax - the maximum point of a scale, $n$ - number of plants of a concrete point, $\mathrm{N}$ - total number of plants
Morphological features of M. microspaera were studied by standard techniques [13 - 15]. Infected, fully developed leaves from apical parts of stems of Quercus robur were collected from early June till late October.

Quantitatively the index of a biodiversity was determined by a formula:

$$
B D=-\sum_{i=1}^{n} p_{i} \times \log _{2} p_{i}
$$

where - BD is biodiversity, $\mathrm{i}$ - elements of biodiversity, pi probability of $\mathrm{i}, \mathrm{n}$ - number of investigated groups.

The test object was oak powdery mildew (Erisiphae alphitoides). Among the oaks, Quercus robur is most susceptible to powdery mildew. E. alphitoides is well known as pathogen of different oaks leaves. Especially newly planted trees are damaged. Older trees are less affected. Variability of morphology and other aspects of a life of $E$. alphitoides should be considered by working out the actions for protection of oak plantings from this pathogen.

Infected of this pathogen completely developed leaves from apical parts of stems of Quercus robur were randomly collected from early June till late October. The investigated plants were 5-10-year-old trees. The material was transported directly in laboratory of Voronezh State Forest University.

The observations were made directly after collection of infested leaves. Each investigated parameter was measured about 30 samples. In total, 320 conidia, 340 cleistothecia, 120 ascospores were measured. Samples for light microscope were prepared with lactophenol. Mycelium was taken from the upper side of leaves.

Researches were spent from the positions of geneenvironment interactions. Such approach is justified. Modelling methods were more widely used.

The results of measurements of morphological parameters were subjected to analysis of variance and discriminant analysis. Dimensions of cleistothecia were subjected to analysis of variance, and the significance of differences between different oak sites. The similar technique has been applied and concerning a fungus Heterobasidion annosum. Skilled-industrial objects have been put in the enterprise of the Voronezh forest university in pure pine plantings in 1936.

\section{Sustainable Development of Forest Ecosystems}

The purpose of the investigation consists in providing forest protection against pathogenic organisms using the phenomenon of the inbreeding depression of the pathogen population. In essence, decreased fitness of a population is based on regulation of gene-environment interactions. This approach, as especially convincingly for the first time showed K. Gayer [12] and then A. Scamoni [16], is most perspective in forest protection and it should be to forest plantings of many regions of our planet. But now there is a gap of knowledge in this sphere and practically the phenomenon of inbreeding is not used in forest protection.

Long-term researches of a role of inbreeding in 
pathogenesis regulation were carried out in forest plantings of Central Russian forest-steppe. Test object - oak powdery mildew (Erisiphae alphitoides). Among the oaks, Quercus robur L. is most susceptible to powdery mildew. E. alphitoides is well known as pathogen of oak leaves. Especially newly planted trees are damaged. Older trees are less affected.

The purpose of this investigation was reached through ecological isolation of protected plantings on enough limited sites $\approx 0,25$ ha. Inbreeding results in increased homozygosity of pathogenic populations, in chances for two alleles to be identical by descent, the chances of offspring being affected by recessive or deleterious traits. Therefore inbreeding leads to a decreased fitness, vigor of a pathogenic population. Inbreeding results usually in phenotypic expression, which is in physical and health defects: smaller size, reduced fertility. Inbreeding is useful as the key factor of forest protection against pathogenic organisms.

Infected fully developed oak leaves of young trees from apical parts of stems of oak in three different forest stands were collected.

A variety of forms of mycelium on leaves were observed. The mycelium appeared in two forms: (1) felted oval patches, and mealy mycelium along veins. Discoloration was typical for the leaves infected with powdery mildew. The morphology of the pathogen testified a state of health of its population. Descriptions of the fungus morphology can diagnose a state of health of its population. The inbreeding as a key factor of forest protection, promoted activity of concomitant forest protection factors, such as effects of ecotone and mycorrhiza.

On a powdery mildew on oak leaves example the principal conclusion from position of forest protection is following: heterogeneous forest ecosystems are more preferable than homogeneous ones.

Sustainable development is understood here as the principle of formation of the forest plantings capable to selfcontrol and self-development. Thus the economic and social functions have to be at the really desirable level. The bases of sustainable development are the integrity and stability of forest systems, which are closer to Nature. This concept of sustainable development is derived mostly from the 1987 Brundtland Report. It is also rooted in earlier ideas about sustainable forest management and twenties century environmental great concerns.

Human-made forest ecosystems have to correspond to idea of population equilibrium, as basis of homeostasis. Sustainability in forest ecosystems can be used in the practice of maintaining processes of productivity indefinitelynatural biotic system or human made.

Sustainable development has its roots in ideas about sustainable forest management which were developed in Europe during the seventeenth and eighteenth centuries. The concept of sustainable development of forest ecosystems has shifted to focus more on environmental protection and social development for future generations.

Mycological aspect of forest growing is important for understanding the role of different group of fungi in forest plantings.

Functional role of fungi in forest ecosystems: formation of a humus (saprotrofs), additional food of trees (simbiotrofs), parasitism (parasits).

Research objective was to increase of plantings viability through formation of ecosystems, favorable for saprotrof and simbiotrof, but adverse for parasites. Results were shown in Table 2.

Table 2. Composition of Fungi Groups in the Various on the Level of Complexity Plantings.

\begin{tabular}{lll}
\hline Structure of plantings & \multicolumn{1}{c}{ Composition of fungi groups } \\
\hline Heterogeneous (mixed) plantings, & \multirow{2}{*}{ No 1} & 0.42 Saprotrofs \\
H = 8,42 bits & & 0.28 Simbiotrofs \\
& & 0.30 Parasits \\
& \multirow{2}{*}{ No 2} & 0.18 Saprotrofs \\
Homogeneous (pure) plantings of & 0.60 Parasits \\
a pine, $\mathrm{H}=3,62$ bits & & 0.27 Saprotrofs \\
& \multirow{2}{*}{ No 3} & 0.23 Simbiotrofs \\
Homogeneous (pure) plantings of & 0.50 Parasits \\
an oak, $\mathrm{H}=5,41$ bits & & \\
\hline
\end{tabular}

As visible in table 2, the complex of fungal species No. 1 as in it mushrooms, useful to the wood, dominate is optimum.

Dependence of viability of plantings on complexity of plantings is shown in table 3 .

Table 3. Viability (State of Health) of Plantings Various of Their Complexity.

\begin{tabular}{ll}
\hline Degree of planting complexity, bit & Viability of planting, point \\
\hline High: $>8$ & 4,65 \\
Average: $5-8$ & 3.62 \\
Low: $<5$ & 3.44 \\
\hline
\end{tabular}

As visible in table 3, with complexity increase the viability (state of health) of plantings improves. The mycological aspect should be considered at forest growing.

\section{Effect of an Inbreeding Depression}

Inbreeding, understood as the reproduction from the mating of genetically related parents, results in increased homozygosity. Basically it raises chances of the offspring being affected by recessive or deleterious traits. Inbreeding leads to a decreased fitness of a population. The phenomenon of inbreeding depression has been used by me for suppression of populations of pathogenic fungi Heterobasidion annosum and Erisipphe alphitoides. These pathogens are well-known, wide distributed, economic important, and they are pleomorph.

The purpose of forest protection was reached through forming mosaic plantings in the Central Russian forest steppe. Mosaic plantings are formed by means of ecological barriers. Inbreeding results in increased homozygosity in pathogenic populations. Inbreeding leads to a decreased fitness of a pathogenic population. It results in phenotypic expression, in physical and health defects of the pathogens: smaller size, reduced fertility. In essence, decreased fitness of 
a population is based on regulation of gene-environment interactions. This approach is most perspective in forest protection and it should be to forest plantings of many regions of our planet. But now there is a gap of knowledge in this sphere and practically the phenomenon of inbreeding are not used in forest protection.

Results of inbreeding were computed as a percentage of improvement of plantings condition and decrease of pathogenic fungi populations. The reduced genetic diversity results from inbreeding may mean a species may not be able to adapt to changes in environmental conditions. Thus, the phenomenon of inbreeding can be recommended as an effective method of preventive protection of forest from pathogenic organisms.

Long-term (2004 - 2013 years) researches in the opened and ecologically isolated oak plantings of Central Russian Upland were carried out. The features of population developments of powdery mildew in opened and ecologically isolated on rather small sites were studied.

\subsection{Ecological Isolation in Forest Ecosystems}

Results of researches with a model pathogenic fungus Erysiphe Alphitoides

The range of investigated areas characterised various conditions for development of pathogenic organisms: young (6...10 years) linear oak cultures, adult (uneven-aged) linear oak cultures, the groups of young ( $6 \ldots 10$ years) oak cultures, young $(6 \ldots 10$ years) oak cultures ecologically isolated on the small areas $(\approx 0,25 \mathrm{ha})$. Ecological isolation of oak plantings has been carried out by pine plantings.

Dynamics of oak powdery mildew development in various conditions is shown that disease development of $M$. alphitoides in linear young oak cultures and in adult oak cultures had the tendency to increase while disease development of M. alphitoides in group oak cultures and in oak cultures ecologically isolated on the small areas $(\approx 0,25$ ha) tended to fall $[1,22]$.

Practical interest represents development of oak powdery mildew oak powdery mildew at a combination of biogroups with ecological isolation of this plantings (Table 4).

Table 4. Calculated Development of Oak Powdery Mildew at Combination of Biogroups with a Planting Isolation.

\begin{tabular}{llcc}
\hline \multirow{2}{*}{ Allocation of trees } & \multicolumn{3}{l}{$\begin{array}{l}\text { Settlement development of oak } \\
\text { powdery mildew on the years, D\% }\end{array}$} \\
\cline { 2 - 4 } & $\mathbf{2 0 0 6}$ & $\mathbf{2 0 0 8}$ & $\mathbf{2 0 1 0}$ \\
\hline $\begin{array}{l}\text { Combination of biogroups } \\
\text { with isolation of plantings }\end{array}$ & 17,5 & 0 & 0 \\
\hline
\end{tabular}

The results from table, years of investigations suggest that the effect of suppression of $M$. alphitoides population can be concerning for others pathogens.

Ecological isolation of an oak by a pine in relative big quadrogroup causes reproductive isolation of the pathogen. Inbreeding arises in a macrogroup of the pathogem - the reproduction from the mating genetically related parents. It is known that inbreeding results in increased homozygosity.

Thus the chances increase that offspring being affected by recessive or deleterious traits. Inbreeding leads to a decreased fitness of a pathogen population. This phenomenon is expressed in reduction of number and sizes of fruit bodies cleistothecia (Table 5).

Table 5. Relative Development of Cleistothecia of Oak Powdery Mildew in the Conditions of Open Oak Forests and Ecologically Isolated Oak Plantings.

\begin{tabular}{lll}
\hline \multirow{2}{*}{$\begin{array}{l}\text { Conditions of oak } \\
\text { growth }\end{array}$} & \multicolumn{2}{l}{ Parameters of cleistothecia } \\
\cline { 2 - 3 } & Diameter, $\boldsymbol{\mu m}$ & Frequency, $\mathbf{n} / \mathbf{c m}^{\mathbf{2}}$ \\
\hline Open stands & 99 & 62 \\
Isolated stands on 0,20 ha & 87 & 8 \\
Note. At statistical accuracy; $\mathrm{P}=10 \%$, significance $\alpha=0,05(\mathrm{t} \approx 2)$ \\
\hline
\end{tabular}

The development of the M. alphitoides fruit bodies (cleistothecia) in isolated oak stands on the rather small area is strongly reduced. In relative small biogroups, the peripheral trees protect internal trees both from primary inoculation of the pathogen. The biogroup functions as a uniform organism in which peripheral trees promote growth and development of the central trees. In small biogroups natural selection is active. Besides, in space between small biogroups the natural biodiversity is formed which as a whole raises stability of created plantings. Small biogroups of wood plants always win a competition to grassy plants.

In the centre of biogroup it is desirable to place individuals from posterities of bioresistant trees ( $R R$ and $R$ ). In the peripheral part individuals from posterities of the middle population trees are located. The recommended structure of forest plantings excludes possibility of mass reproduction and wide distribution of pathogenic organisms. In the space between biogroups of different tree species the natural biodiversity is formed. The tree biogroups successfully compete to surrounding grassy vegetation. The forest environment as a whole improves.

Inbreeding, as the reproduction from the mating of genetically related parents, is usual in the wild nature. As purposeful process, inbreeding is widely applied in selection of plants and animals. Inbreeding results in increased homozygosity. Homozygosity can increase the chances of offspring being affected by recessive or deleterious traits. The homozygosity of offspring usually rises, because the number of identical alleles in their genomes of the subsequent individuals increases. Homozygosity reduces fitness of population, weakens it that is causes inbreeding depression.

The purpose is to use the factor of the inbreeding depressions for suppression of pathogenic populations in forest ecosystems. Inbreeding in the ecosystems is reached as a result of reproductive isolation of pathogenic organisms. Inbreeding leads to a decreased fitness of a population. The researches were spent in the Central Russian forest-steppe. Modelling test objects were the economically significant and well-known fungi E. alphitoes, $H$. annosum and Porodaedalea pini.

The phenomenon of inbreeding in biological systems is based on gene-environment interactions and can be used as a key factor of forest protection against pathogenic organisms. The purpose of the study is to protect pine (P. sylvestris) and 
oak (Q. robur) forests against infectious diseases caused accordingly by fungi $H$. annosum and E. alphitoides. The purpose of forest protection is reached through forming mosaic plantings. Mosaic plantings are formed by means of ecological barriers. Inbreeding results in increased homozygosity in pathogenic populations. Inbreeding leads to a decreased fitness of a pathogenic population. It results in phenotypic expression, in physical and health defects of the pathogens: smaller size, reduced fertility. Inbreeding is useful as the key factor of preventive forest protection.

\subsection{Populations of the Ascomycete E. Alphitoides}

The basic results of research according to Erysiphe alphitoides are presented in table 6 .

Table 6. Specificity of E. Alphitoides Development in Open and Ecologically Isolated Plantings of the Q. Robur Plantings.

\begin{tabular}{|c|c|c|c|c|c|}
\hline \multirow{2}{*}{$\begin{array}{l}\text { Growth conditions } \\
\text { of oak }\end{array}$} & \multirow{2}{*}{$\begin{array}{l}\text { Disease development } \\
\text { D\% }\end{array}$} & \multicolumn{2}{|l|}{ Conidia } & \multicolumn{2}{|l|}{ Cleistothecia } \\
\hline & & Length, $\mu \mathrm{m}$ & Width, $\mu \mathrm{m}$ & Diameter, $\mu \mathrm{m}$ & Placing density, $\mathbf{n} / \mathrm{cm}^{2}$ \\
\hline Open plantings & 78 & 32 & 18 & 99 & 64 \\
\hline Isolated plantings & 16 & 24 & 13 & 74 & 8 \\
\hline
\end{tabular}

The note to table 7: (1) n- number of cleistothecia, (2) the investigated two groups of parametres were significantly $(\mathrm{p} \leq$ $0,05)$ different.

As it is shown on the table 6, key parametres of E. alphitoides population development in open plantings and isolated plantings are different. The given results of researches quite correspond to genetic interpretation of a phenomenon of pathogenesis.

Disease development in open oak plantings tends to unlimited growth, and on the contrary, in the isolated oak plantings disease caused of the fungus E. alphitoides tends to attenuation. This phenomenon is a consequence of inbreeding in pathogenic population in the oak ecologically isolated on limited sites plantings. The fact of inbreeding proves to be true and features of morphology of the pathogen in the conditions of isolated oak plantings. Differences in size of conidia were found. The $95 \%$ confidence of length and width of conidia in the two groups has been established.

On a powdery mildew on oak leaves example the principal conclusion from position of forest protection is: heterogeneous forest ecosystems are more preferable than homogeneous ones.

\subsection{Populations of the Basidiomycete Fungus Heterobasidion Annosum (Fr.) Bref}

Annosum root rot is one of the most harmful diseases of pine plantings of the Central Russian Upland. The considerable package of measures on pine protection against the $H$. annosum is recommended. $H$. annosum is widespread in pine forests in Russia and is responsible for the great loss annually. This fungus has been known by different names. Commonly, it is known as annosum root rot. This pathogen is one of the most destructive diseases of conifers, in the Central Russian Upland especially Scots pine.

In distribution of annosum-diseases the structure of plantings can be of great importance (Table 7-9).

The distribution of $H$. annosum in soil within the pathogen center in open pine plantings occurs more intensively, than in isolated on relative small patches of pine. The soil was investigated at a depth of $5 \mathrm{~cm}$. At a depth of $5 \mathrm{~cm}$ cases of infection of roots with a pathogen were registered. The most of the infected trees were eventually dies off.
Table 7. Distribution of H. Annosum in the Soil of the Open and Ecologically Isolated Pine Plantings Within the Pathogen Center.

\begin{tabular}{llll}
\hline $\begin{array}{l}\text { Pine } \\
\text { plantings }\end{array}$ & $\begin{array}{l}\text { Number of } \\
\text { tests }\end{array}$ & $\begin{array}{l}\text { \% of } \\
\text { infections }\end{array}$ & $\begin{array}{l}\text { Variability, } \\
\mathbf{S x} \%\end{array}$ \\
\hline Open & 60 & 86,4 & 24 \\
Isolated & 60 & 12.3 & 38 \\
\hline
\end{tabular}

The size of $H$. annosum conidiospors was smaller in isolated pine plantings in comparison of disputes conidiospors in open plantings (Table 8). This fact shows that the isolated population of a pathogen degrades. The fungus colonizes and moves short distances into the root via mycelium. Fungus cannot move very far in its own soil

Table 8. Size of H. Annosum Conidiospors (Asexual Spores) in the Open and ecologically Isolated Pine Plantings Within the Pathogen Center.

\begin{tabular}{llllll}
\hline $\begin{array}{l}\text { Pine } \\
\text { plantings }\end{array}$ & $\begin{array}{l}\text { Number } \\
\text { of tests }\end{array}$ & Length & $\begin{array}{l}\text { Variability, } \\
\mathbf{S x} \%\end{array}$ & Width & $\begin{array}{l}\text { Variability, } \\
\mathbf{S x} \%\end{array}$ \\
\hline Open & 24 & 6.1 & 18 & 4.6 & 18 \\
Isolated & 24 & 3.2 & 14 & 2.3 & 14 \\
\hline
\end{tabular}

Presence of conidiospores in air was studied with use of the agar-glasses located at the height of $1 \mathrm{~m}$. It is established that in the conditions of isolation the number of conidiospores in air is much less, than in open pine plantings In the conditions of the center of H. annosum.

Table 9. Number of Conidiospors in the Air (on $1 \mathrm{~cm}^{2}$ of Integumentary Glass) in the Open and Ecologically Isolated Pine Plantings Within the Pathogen Center.

\begin{tabular}{llll}
\hline Pine plantings & $\begin{array}{l}\text { Number of } \\
\text { tests }\end{array}$ & $\begin{array}{l}\text { Number of } \\
\text { conidiospors }\end{array}$ & $\begin{array}{l}\text { Variability, } \\
\mathbf{S x} \%\end{array}$ \\
\hline Open & 110 & 3.17 & 64 \\
Isolated & 110 & 0.12 & 12 \\
\hline
\end{tabular}

Sexual spores created from the basidiocarps were not found. During researches the asexual stage of the pathogen dominated. When the infected trees die it causes gaps in the forest canopy, which affects the moisture and sunlight available, altering the habitats for plants and inhabitants on the forest floor. The role of conidiospores is the main in the infection process and is thought to be most important.

For many years $H$. annosum has been closely investigated in many countries as a facultative parasite of plantings grown 
pine. As a facultative parasite this pathogen always presents at pine plantings of Central Russian forest-steppe. Homogeneity of plantings provokes mass reproduction of the pathogen. Heterogeneity of pine plantings constrains mass reproduction of the pathogen.

This fact shows that the isolated population of a patgogen degrades. But the problem remains as the recommended protective measures are unacceptable from ecological or economic positions and are insufficiently effective.

The purpose of this investigation is to radical increase the efficiency of preventive protection of a pine against a root rot on eco-genetic basis. In subpopulations of the pathogen, the effects of an inbreeding depression, allelic drift and pine group resistance to the pathogen arise. Mosaic forest ecosystems most correspond to the principle of a sustainable development of plantings in the conditions of the changeable environment.

\subsection{Coefficient of an Inbreeding Depression}

Inbreeding as the reproduction from the mating of two genetically related parents, which can increase the chances of offspring being affected by recessive or deleterious traits, can be of great importance in regulation of pathogenesis in forest ecosystems. Inbreeding generally leads to a decreased fitness of a population of pathogens. This phenomenon is inbreeding depression.

Inbreeding may result in a phenotypic expression. As a result, first-generation inbred individuals are more likely to show physical and health defects. They can include: reduced fertility, lower birth rate, higher mortality, slower growth rate, smaller adult size, loss of immune system function.

Natural selection works to remove individuals with adverse types of traits from the gene pool. Therefore, the part of individuals in the first generation of inbreeding will never live to reproduce. Over time, in the conditions of isolation, the deleterious inherited traits are culled. As results, the reduced from inbreeding genetic diversity is not enough for species to adapt to changes in environmental conditions.

As discussion of research it is offered phenotypical coefficient for an estimation of the inbreeding force to depression a pathogenic population:

$$
\text { C I } p h=d 1-d 2 d,
$$

wo CIph is - phenotypical coefficient of inbreeding depression, $\mathrm{d} 1$ - the development of diseases in the open plantings, $\mathrm{d} 2$ - the development of diseases in the isolated on $\approx 0,25$ ha forest plantings.

Application of this formula in forestry showed good results.

\section{Group Effect in Resistance of Forest Tree Populations}

The space between biogroups grows naturally. It is a basis of resistant plantings. The effect of inbreeding in populations of pathogenic organisms is thus reached. Inbreeding results in increased homozygosity that can increase the chances of offspring being affected by recessive or deleterious traits. Inbreeding leads to a decreased fitness of a pathogen population (inbreeding depression). Pathogenesis regulation is necessary, to sustain wood ecosystems in their struggle against harmful organisms. As the pathogenesis is defined both environmental conditions and hereditary factors of hosts and pathogens, pathogenesis regulation should have genetikecological basis.

The offered system of improvement of wood plantings is inconsistent perceived by practical foresters as it complicates a little the technology of reforestation. It is the truth but advantage of offered reforestation is more than a technology complication. Improvement of wood and environment regulation on this basis is reached.

Naturalness of group placement of trees in forest communities was directly or indirectly reflected in many works (Darwin, 1859; Scamoni, 1954; Schütt, 1957; Stephan, 1986; Rajanow, 1995; Rohmeder, 1959; Wright, 1937, 1951, 1976; Zaspel, 2002). Group placement of trees is applied in the Central Russian forest-steppe Upland (Figures 8, 9, 10).

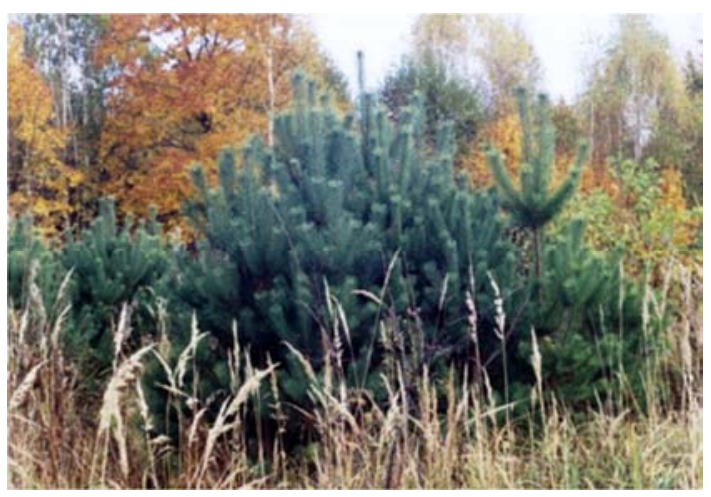

Figure 8. Young Group of a Pine.

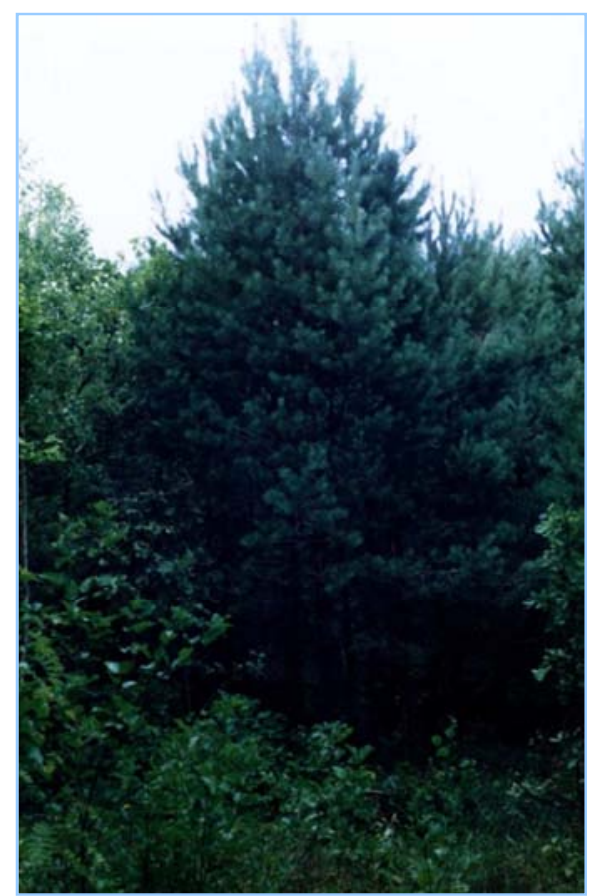

Figure 9. Middle-Aged Group of a Pine. 


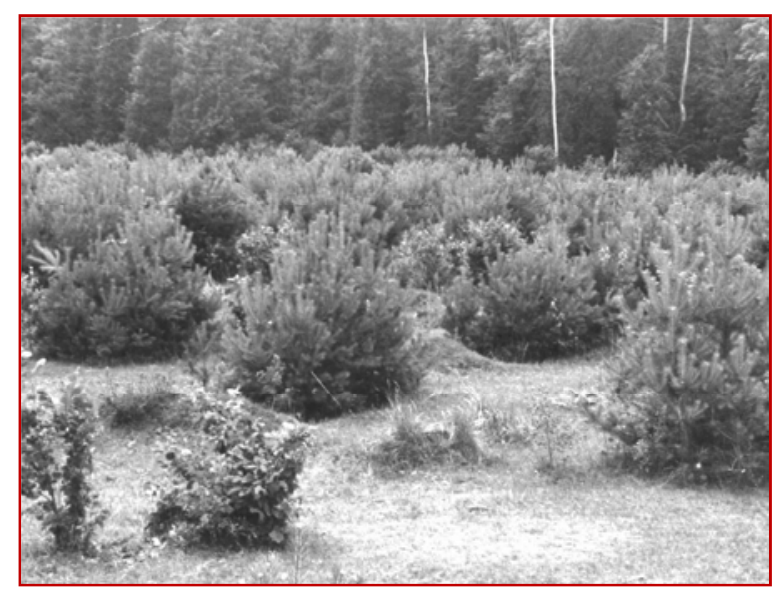

Figure 10. Group Planting of a Pine.

\section{Mosaic Forests}

Mosaic plantings (Figure 11) are recommended as a most adaptable in the Central Russian Apland.

The forecast of pathogenesis in forest ecosystems owing to multifactorial diseases is always stochastic. High degree of determinacy of the forecast is possible in heterogeneous plantings. The works purpose - the long-term preventive control of pathogenesis - is reached through formation enough heterogeneous plantings. In the complex heterogeneous dynamical forest ecosystems the stochastic forecast of pathogenesis is replaced with the forecast close to the determined. Such forecast is a basis for the control of pathogenesis. Transition from formation of homogeneous plantings to heterogeneous is recommended.

The forecast of pathogenesis in forests, which is mainly homogeneous ecosystems owing to its multiple dependences on various factors, is always probabilistic. Rather high degree of determination of the forecast is possible in more complex heterogeneous plantings. In complex forest ecosystems the probabilistic forecast of pathogenesis is replaced with the forecast close to the determined. Such forecast can be a basis for pathogenesis control. For homogeneous forest plantings is unpredictability of epiphytoties characteristic while for heterogeneous plantings smooth authentically predictable fluctuations of pathogenesis are characteristic. Thus pathogens often pass to saprotrophic nutrition. This phenomenon is especially characteristic for highly heterogeneous mosaic plantings.

The hierarchy of purposes of the researches consists in that through rather determined forecast to provide effective control of pathogenesis and to offer conceptual models of plantings, resistant against pathogenic organisms. As biological systems forest plantings are characterized by the increased complexity and dynamism. The influence on pathogenesis of many changing factors creates randomness, widespread in the nature. The actual task consists in that to transform chaotic behavior of forest ecosystems to adjustable process. Thus long-term forecasts of pathogenesis become less dependent on external influences and to be defined by mainly internal factors of biosystem.
The methodology of researches is based on the application of the three- factorial analysis of influence of the studied factorial groups on viability (state of health) of plantings. The researches were carried out in plantings of the Central Russian forest-steppe, various on heterogeneity level, within the last 10 years. It was established that on force of influence the environment dominated. Factors of influence of the pathogen and host populations were modifying. That longterm forecasts of pathogenesis became less dependent on external influences and depended more on internal factors of biosystems it is recommended to pass from usual in the Central Russian forest-steppe homogeneous plantings to heterogeneous.

The decision of an actual problem of natural suppression of pathogenic populations in forest ecosystems is offered. For this purpose the effect of inbreeding depressions is used. The pathogenic populations are divided on the limited enough reproductive isolated subpopulations. The isolation of subpopulations is reached by means of ecological barriers. As the modal test object, the ascomycetes Erysiphe alphitoides was investigated.

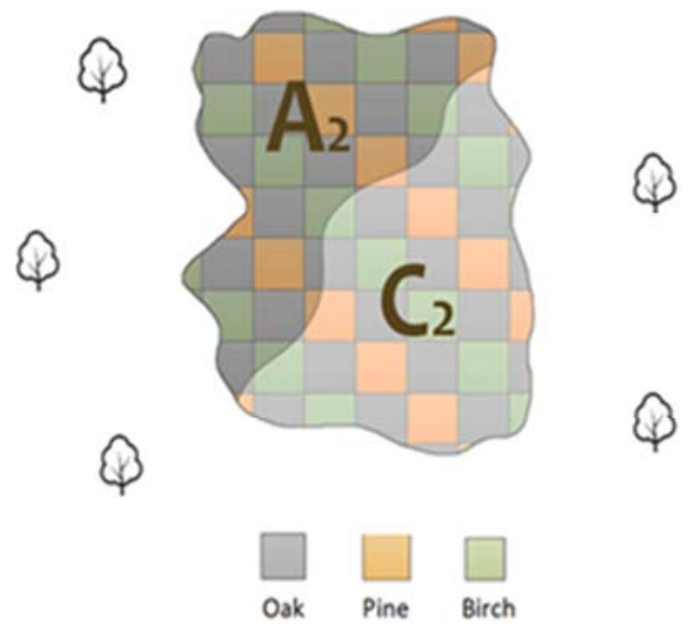

$\mathrm{A}_{2} \& \mathrm{C}_{2}$ are different growing conditions

Figure 11. Mosaic (Oak, Pine, Birch) Planting.

\section{Biotic Integration}

Integration, concerning forest ecosystems, means coherence of the differentiated parts in time. As a relative measure (criterion) of biotic integration in forests can be accepted the middle year's level of resistance viability. It is proved that in a Scots pine (Pinus sylvestris), English common oak (Quercus robur) including pen stands in Central Russian forest-steppe zone diverse-rich well integrated forest communities are able to recover faster from disturbances than diverse-poor and disintegrated communities. Biotic integration is necessary for development stability of forest systems. The relationships between community diversity and stability highlight the need to maintain the greatest richness within investigated pine, oak stands. Biotic integration forms close to nature forest plantings. This understanding is necessary for practical activities. A foundation for 
sustainable management of forest ecosystems is biotic integration, related to biodiversity. Well integrated biological communities are healthy communities.

Woods of each country are not only its national riches, but are at the same time also property of all world and have a huge global ecological value. Therefore the transparency in multi-purpose use of woods and in an objective estimation of a state of woods is necessary. It is possible to assert precisely that in recent history the situation related to health and quality of woods in the Central Russian forest-steppe was constantly worsened. A deep disharmony was generated in biotic relations, first of all between forest plants and its consuments, between biocoenosis and biotopic potential. The main reason of these disturbances is malmanagement of forest ecosystems. The interactive relationships between populations of different forest species, co-evolutionary processes, the organization and functioning of communities; natural niches and guilds have been broken.

Environment impacts on forest ecosystems. The problem consists in improving multi-objective forest plantings of Central Russian forest-steppe zone. It is offered to solve the problem on a genetic-ecological basis. A large number of superior appearing plants should be selected.

Mass selection can be very effective in improving resistance characters and applied over many generations. As populations of species interact with one another, they form resistant biological communities.

Our purpose is to make more active integration processes in the managed forest ecosystems in the Central Russian forest-steppe zone. Basis for that is the high level of biodiversity, selection of forest trees on bioresistance trees, and formations of the forest environment, adverse for pathogenic organisms.

It was selected to three main key factors of biodiversity that can influence the vitality of Scotch pine forest stands: composition diversity (pure plantings - mixed plantings), structural diversity (linear placing of trees - group placing of trees), intra-population diversity (participation of two Scotch pine races - resistant and sensitive to $H$. annosum, \%). Progenies of valuable plus trees were selected and tested in last decades. Intra-population diversity was determined on the basis of publications of [F. Pravdin and S. A. Mamaev. Intrapopulation diversity was explored by examining its effects on the observable characteristics of individuals in populations.

Survey and research works were carried out in Tsninsky (in northern part of forest- steppe), Usmansky (in an average part of forest-steppe), Khrenovsky (in a southern part of a foreststeppe zone) large forests during 2007 - 2009 years. Researches have been carried out in the pure motley grass pine (Pinetum sylvestris) and mixed motley grass pine-oak (Pinetum-Quercetum sylvestris) plantings. In total it has been put $144(48 \times 3)$ circular trial areas in the pine-oak grass forests. The technique of laying the circular trial areas and carrying out of researches is based on publications of $\mathrm{A}$. Pommering and $\mathrm{P}$. Biber [13], H. Pletzsh [14, 15], A. Scamoni [16], K. Hölzer [17], E. Rohmeder, H. Schönbach [18].

Researches have been carried out in the middle-aged and premature-age Scotch pine and English oak plantings. Pine trees had II quality klass, oak trees had III quality class. The ash-tree (Fraxinus axcelsior), maple (Acer platanoides), birch (Betula pendula), aspen (Populus tremula) and others were accompanying breeds. Among bushes prevailed hazel (Corylus), hawthorn (Crataegus), elder (Sambucus racemosa), common maple (Acer campestre). Among grassy plants prevailed common cat's-foot (Antennaria dioica), mouse-ear hawkweed (Hieraclum pilosella).

The dispersive 3-factors analysis was used to investigate how forest biodiversity is preferable determined in the investigated area (Table 10). This table was parametrized for different environment conditions.

Table 10. The Influence of Key Factors on Pine Forest Viability (V) in Tsninsky Large Forests.

\begin{tabular}{lll}
\hline Factors and their combinations & Strength characteristics of the influence & $\begin{array}{l}\text { Rank of the influence of intra-population diversity on the pine } \\
\text { forest viability }\end{array}$ \\
\hline Factor A: intra-population diversity & 6.057 & 1 \\
Factor B: structural diversity & 1.300 & 3 \\
Factor C: composition diversity & 4.623 & 2 \\
Combination & 0.676 & 4 \\
Combination & 0.502 & 5 \\
Combination & 0.267 & 7 \\
Combination & 0.499 & 6 \\
\hline
\end{tabular}

Mean score of viability of investigated plantings $=2.68$ points $\sum$ of strength $=13.93$.

Table 11. The Influence of Three Key Factors on Pine + Oak Forests Viability (V) in Usmansky Large Forest.

\begin{tabular}{lll}
\hline Factors and their combinations & Strength characteristics of the influence & $\begin{array}{l}\text { Rank of the influence of intra-population diversity on the pine } \\
\text { forest viability }\end{array}$ \\
\hline Factor A: intra-population diversity & 3.035 & 1 \\
Factor B: structural diversity & 2.083 & 3 \\
Factor C: composition diversity & 2.707 & 2 \\
Combination & 0.240 & 6 \\
Combination & 0.322 & 5 \\
Combination & 0.067 & 7 \\
Combination & 0.034 & 4 \\
\hline
\end{tabular}

Mean score of viability of investigated plantings $=2.49$ points $\sum$ of strength $=11.82$. 
As visible in table 11 the intra-population diversity has greatest value in the influence on the viability. The intrapopulations diversity is the prerequisite for the adaptability of forest populations to different environment conditions, to the changeable world. It is a great chance to survive for pine by genetic diversity. A possible reduction of genetic diversity may lead to a reduction in adaptability of forest trees. The purpose is to keep adaptation to different growth conditions.

The structural diversity (linear placing of trees $\div$ group planting of trees) of plantings can be the effective regulation factor of a sustainable development of forest ecosystems. Biogroups can be especially effective. Mean score of investigated plantings $=2.68$ points, that is approximately an average level of plantings viability.

The relationships between species diversity and community stability highlight the need to maintain the greatest richness within forest communities. That can significantly contribute to improved forest management.

Table 12. The Influence of Three Key Factors on Pine + Oak Forests Viability (V) in Khrenovsky Large Forest.

\begin{tabular}{lll}
\hline Factors and their combinations & Strength characteristics of the influence & $\begin{array}{c}\text { Rank of the influence of intra-population } \\
\text { diversity on the pine forest viability }\end{array}$ \\
\hline Factor A: intra-population diversity & 0.947 & 2 \\
Factor B: structural diversity & 1.650 & 1 \\
Factor C: composition diversity & 0.775 & 3 \\
Combination & 0.422 & 4 \\
Combination & 0.329 & 5 \\
Combination & 0.231 & 6 \\
Combination & 0.0167 & 7 \\
\hline
\end{tabular}

Mean score of viability of investigated plantings $=2.43$ points $\sum$ of strength $=4.52$.

Integration, concerning forest ecosystems, means coherence of the separate differentiated parts of forest in a single whole and also process of well regulating, and associating of the differentiated structures and functions in complete biological systems. This understanding is necessary for practical activities.

The basic idea of biotic integration in forest ecosystems is based on respect for "a free choice of the nature". Biotic integration forms close to nature forest plantings when the plantings close to the natural woods are formed. This approach of formation of forest ecosystems does not contradict a position of H. A. Fowelles [19], H. Muchs [20], and T. A. Furukoshi [21]. But actions for creation and reconstruction of artificial forests closed to nature are not aimed at restoration prehistoric or later but not corresponding to modern conditions. Only, principles of natural regulation of biotic relations in forest communities which remained invariable are used. Biotic integration forms close to nature forest plantings. The organisms which have originally appeared on our planet became complicated, developed during evolution in interdependence. In the identical biotops the certain, in particular wood systems, were gradually formed. The degree of biotic integration in them gradually rose. High level of heterogeneity will lead to the maintenance of ecological autonomy and equability of artificial forest. Economically formation of high-heterogeneous plantings has to be assigned to management of the forests.

\section{Conclusions}

Spontaneus development of forests is desirable because it carries out to free choice of the forest dwellers. The harmonious biological community which develops in the changeable World more steadily is formed. It is necessary for improvement of environment and for health of the forests.
Especially this problem is topical in the of the Central Russian forest-steppe, where some forest parasitic fungi and insects are very active. Global warming and a wrong human activity can significantly worsen health of the forests even more. Mosaic highly heterogeneous forest ecosystems form the forest environment closest to natural and will be a longterm basis of radical improvement of health of forest plantings.

\section{References}

[1] Arefjew, Ju. F.: Genetisch-ökologische Aspekte des Forstschutzes. Der Wald, 7'95, Berlin (1995), S. 238 - 239.

[2] Björkman, E.: Resistance to snow blight (Phacidium infestans Karst.) in different provenances of Pinus sylvestris. Stud., 5, (1963). P. $2-3$.

[3] Björkman, E.: Breeding for resistance to disease in forest trees. Unasylva, vol. 18 (1964). P. 1 - 16.

[4] Flor, H. H.: Current status of the gene-for-gene concept. Ann. Rev. Phytopath., 9, (1971). P. 275 - 296.

[5] Mendel G.: Versuche über Pflanzen-Hybriden, Verh. naturforsch. Vert. Brünn, 4, (1866). S. 3-47.

[6] Hardy, G. H.: Mendelian proportions in a mixed population. Science, 28, (1908). P. 49 - 50.

[7] Weinberg, W.: Weitere Beiträge zur Theorie der Vererbung, Arch. Rassenges. Biol. 7. (1910). S. 35-49, 169-73.

[8] Li, C. C.: The correlation between parents and offspring in random mating population. Am. J. Hum. Genet. (1954). P. 383 -386 .

[9] Li, C. C.: First course in population genetics. California, The Boxwood pressw, (1976). 555 p. 
[10] Löchelt, S.: Bestimmung der genetischen Konstitution von Waldbäumen mit unterschiedlich ausgeprägten Scadsimptomen auf baden-würtembergischen Dauerbeobachtungsflächen. Project Europäisches Forschungszentrum für Maßnahmen der Luftreinhaltung. Forschungsbericht KfK-PEF 108, (1993). 115 S.

[11] Kurth, H.: Forsteinrichtung. Berlin: Deutscher Landschafsverl., (1994). $592 \mathrm{~S}$.

[12] Gayer, K.: Der gemischte Wald, seine Begründung und Pflege, insbesondere durch Horst - und Gruppenwirtschaft. Berlin: Parey, (1726). - $168 \mathrm{p}$.

[13] Pommerening, A.: Neue Methoden zur Analyse und Characterisierung von Bestandesstructuren. Forstw. Cbl. 119. (2000). S. $62-78$.

[14] Pretzsch, H.: Analyse und Reproduction räumlicher Bestandesstructuren. Methodische Überlegungen am Beispiel niedersächsischer Buchen-Lärchen-Mischbestände. Centralblatt für das gesamte Forstwesen 112. (1995). S. 91 117.

[15] Pretzsch, H.: Structural diversity as a result of silvicultural operations. Forestry 10. (1998). S. $429-439$.
[16] Scamoni, A.: Waldgesellschaften und Waldstandorte. BerlinAcademie-Verlag. (1954). $186 \mathrm{~S}$.

[17] Holzer, K.: First results of of a small provenance trial with Pinus strobus and P. strobiliformis near Vienna. Proc. 18-th IUFRO World Congress. Div. 2. Ljubljana. (1986), N 1. P. 23 -30 .

[18] Rohmeder, E. \& H. Schönbach: Genetik und Züchtung der Waldbäume. Hamburg und Berlin, (1959). - 338 S.

[19] Fowelles, H. A.: Service of forest trees of the United States. Agriculture Handbook, № 271. -Washington, (1965). - 762 p.

[20] Muhs, H.-J. et al.: The conservation of genetic resources in the Federal Republic of Germany. Muhs, A. Behm, H. Dörflinger // Forest, genetics, breeding and physiology of woody plants. Moscow. (1990). P. 79 - 104.

[21] Furukoshi, T. A. \& S. Kurinobu: A provenance trial of Pinus strobus in Central Japan. Forest Plants and Forest Protection. Ljubljan, (1986). P. 1 -12.

[22] Arefjew, Ju. F.: Free Choice of the Nature in the Changing World. Universal Journal of Geoscience, 5, 117 - 137. doi: 10.13189/uig.2017.050501. 